\title{
O CURRÍCULO DE QUÍMICA NA EDUCAÇÃO BÁSICA: Concepções e Práticas de Professores
}

\author{
Nycollas Stefanello Vianna ${ }^{1}$ \\ Jaqueline Ritter ${ }^{2}$
}

\begin{abstract}
RESUMO
O presente artigo traz resultados parciais de uma Dissertação de Mestrado no Programa de Pós-Graduação em Educação em Ciência de uma Universidade Federal do sul do Brasil. Perguntou-se: Que Currículo de Química os professores consideram relevante e sobre quais critérios assenta-se a sua escolha? Ouviu-se professores de Escolas Públicas do Ensino Médio por meio de uma entrevista semiestruturada analisada à luz da metodologia de Análise Textual Discursiva (ATD). O objetivo geral da pesquisa consistiu em reconhecer e interpretar o que pensa e concebe a comunidade de Educação Química (professores) sobre o Currículo de Química na Educação Básica em termos de concepções, discursos e práticas. Reconheceu-se cinco categorias de análise, as quais são apresentadas com proposições, e, para este artigo, optou-se por apresentar três dessas categorias: Currículo Inovador, Currículo Tecnicista e Currículo como discurso/definição. Dentre os resultados percebeu-se que os docentes reconhecem que há a necessidade de um currículo inovador, que relacione os conteúdos científicos com o cotidiano do estudante, bem como contemple metodologias diferenciadas de trabalho em sala de aula, interpretadas no horizonte das condições teórico-práticas.
\end{abstract}

Palavras-chave: Currículo inovador. Currículo tecnicista. Currículo como discurso/definição.

THE CURRICULUM OF CHEMISTRY IN BASIC EDUCATION: CONCEPTIONS AND PRACTICES OF TEACHERS.

\section{ABSTRACT}

This article presents partial results of Master's Dissertation in the Graduate Program in Education in Science of a Federal University of the south of Brazil. It was asked: what curriculum of chemistry do teachers consider relevant and on what criteria is their choice based? It was heard teachers of Public Schools of the High School through a semistructured interview analyzed in light of the methodology of Discursive Textual Analysis (ATD in Portuguese). The general objective of the research was to recognize and interpret what the Chemistry Education community (Teachers) think about the Chemistry Curriculum in Basic Education in terms of conceptions, discourses and practices. Five categories of analysis were recognized, which are presented with propositions, and for this article it was chosen to present three of these categories: Innovative Curriculum; Curriculum Technicality and Curriculum as speech / definition. Among the results it was noticed that the teachers recognize that there is a need for an innovative curriculum, which relates the scientific contents to the daily life of the student, as well as, contemplate differentiated methodologies of work in the classroom; interpreted within the horizon of theoretical and practical conditions.

Keywords: Innovative curriculum. Curriculum technicality. Curriculum as speech/definition.

\author{
RECEBIDO EM: 15/4/2019
}

ACEITO EM: 27/5/2019

\footnotetext{
${ }^{1}$ Licenciado em Ciências da Natureza pela Universidade Federal do Pampa (Unipampa), Campus Dom Pedrito/RS. Mestre em Educação em Ciências pela Universidade Federal do Rio Grande (Furg), Rio Grande/RS. Professor substituto na área de Educação em Química na Universidade Federal da Fronteira Sul (UFFS), Campus Erechim/RS. http://lattes.cnpq.br/4877804316065478. https://orcid.org/0000-00034596-0921. nycollasv@hotmail.com

2 Graduação em Ciências Plenas - Habilitação em Química (Universidade Regional do Noroeste do Estado do Estad do Rio Grande do Sul RS - Unijuí, Ijuí/RS, 2001). Especialização em Gestão e Apoio Pedagógico na Escola Básica - Ênfase em Administração e Supervisão Escolar (Universidade de Cruz Alta - Unicruz, Cruz Alta/RS, 2003). Mestrado (2011) e Doutorado (2015) em Educação nas Ciências (Unijuí, ljuí/ RS). Professora-adjunta da Escola de Química e Alimentos (EQA) da Universidade Federal do Rio Grande (Furg) e professora do quadro permanente do Programa de Pós-Graduação em Educação em Ciências: Química da Vida e Saúde (PPGEC-Furg - Rio Grande/RS). http:// lattes.cnpq.br/0702692587510877.https://orcid.org/0000-0002-8841-3664. jaquerp2@gmail.com
} 
Atualmente são muitos e diversos os estudos realizados na área de Educação em Ciências no Brasil preocupados com o currículo a ser desenvolvido principalmente nas etapas finais da Educação Básica. Para Silva (2006), provavelmente a riqueza dos estudos neste campo decorre do caráter conflitual das diversas concepções de currículo que emergiram nas últimas décadas. Nesse campo de pesquisa surgem algumas questões como: O que pode ser denominado Currículo? Esse currículo pode ser entendido a partir de uma ou mais definições? Esses são alguns dos questionamentos que permearam a realização deste estudo na temática: O currículo de Química na Educação Básica: concepções e práticas de professores.

Para Lopes e Macedo (2011), não é possível responder o que é o currículo, posto que, em uma visão simplista, há o entendimento que o trata como uma listagem de conteúdos que irá nortear as aulas das escolas brasileiras. Entende-se que o currículo não deve ser concebido como um conceito de fácil definição, mas, sim, como uma construção cultural (GRUNDY, 1987) que, segundo Sacristán (1995), supõe a concretização dos fins sociais e culturais e de socialização acerca dos quais se faz a instrumentalização concreta da escola como parte de um determinado sistema social. Compreendendo dessa forma, o currículo é um construto social que apresenta uma história sociocultural de construção e que precisa ser constantemente revista, interpretada e reconstruída. Da mesma forma, o currículo como campo de estudo e pesquisa também apresenta significados históricos que se modificaram e se modificam ao longo do tempo (SMOLKA, 2004). Sendo assim, nos interessou inicialmente reconhecer a história do currículo, para, então, interpretar o Currículo de Química que está na voz dos professores da Educação Básica, considerando que recuperar esses significados e sentidos é essencial para que a Educação em Ciências, como um todo, também evolua, progrida e avance.

Na Figura 1 apresenta-se alguns fatos que são destaques na história do currículo.

Figura 1 - Acontecimentos marcantes da construção sociocultural e histórico-social do Currículo

\begin{tabular}{|ccc|}
\hline $\begin{array}{c}1633 \\
\text { "Surge o } \\
\text { Curriculo" }\end{array}$ & $\begin{array}{c}1960-1969 \\
\text { Balança o pensamento da } \\
\text { estrutura educacional } \\
\text { tradicional. }\end{array}$ & \\
\hline & $\begin{array}{c}1920-1929 \\
\text { "Curriculo" como } \\
\text { objeto de estudo. }\end{array}$ & $\begin{array}{c}1960-1969 \\
\text { Primeiros estudos sobre } \\
\text { Curriculo no Brasil. }\end{array}$ \\
\hline
\end{tabular}

Fonte: Elaborada pelos pesquisadores com base em SILVA (2009).

A primeira vez que se fez menção ao termo "currículo" foi no ano de 1633 na Escócia, mais precisamente na Universidade de Glasgow, referindo-se ao curso integral seguido pelos estudantes (HAMILTON, 1992). É preciso destacar que, conforme Lopes e Macedo (2011), o termo já estava ligado à organização escolar de sujeitos agrupados, sendo essa uma característica presente até os dias atuais em um dos seus sentidos mais consolidados. Para Tomaz Tadeu da Silva (2009), contudo, é somente na década de 
20 (1920-1929) que provavelmente o currículo aparece como um objeto específico de estudo em Universidades nos Estados Unidos, e no Brasil esses estudos emergem em meados de 1960.

No Brasil, a educação é garantida pela Constituição Federal da República em seu artigo 205, como "direito de todos e dever do Estado e da família" (BRASIL, 1988, p. 123) e está assegurada na Lei de Diretrizes e Bases da Educação Nacional - Lei no 9.394, de 20 de dezembro de 1996 - LDBEN (BRASIL, 1996). Segundo a LDBEN/1996, a finalidade da educação básica brasileira é desenvolver o educando, assegurar-lhe a formação comum indispensável para o exercício da cidadania e fornecer-Ihe meios para progredir no trabalho e em estudos posteriores.

Em termos de políticas de currículo, desde a definição de Educação Básica na LDBEN/1996, muitos outros documentos foram sendo produzidos, a exemplo do Plano Nacional de Educação - PNE que determina diretrizes, metas e estratégias para a política educacional no período de 2014 a 2024 (BRASIL, 2014); os Parâmetros Curriculares Nacionais para o Ensino Médio - PCNEM (BRASIL, 1999), seguidos de Orientações Curriculares Nacionais e, mais recentemente, as novas Diretrizes Curriculares Nacionais para o Ensino Médio - DCNEM (BRASIL, 2012), dentre outros que estão em fase em discussão/aprovação.

Na Figura 2 apresenta-se um resumo sobre a organização da Educação Básica no Brasil de acordo com a LDB (BRASIL, 1996).

Figura 2 - Resumo da organização da Educação Básica Brasileira

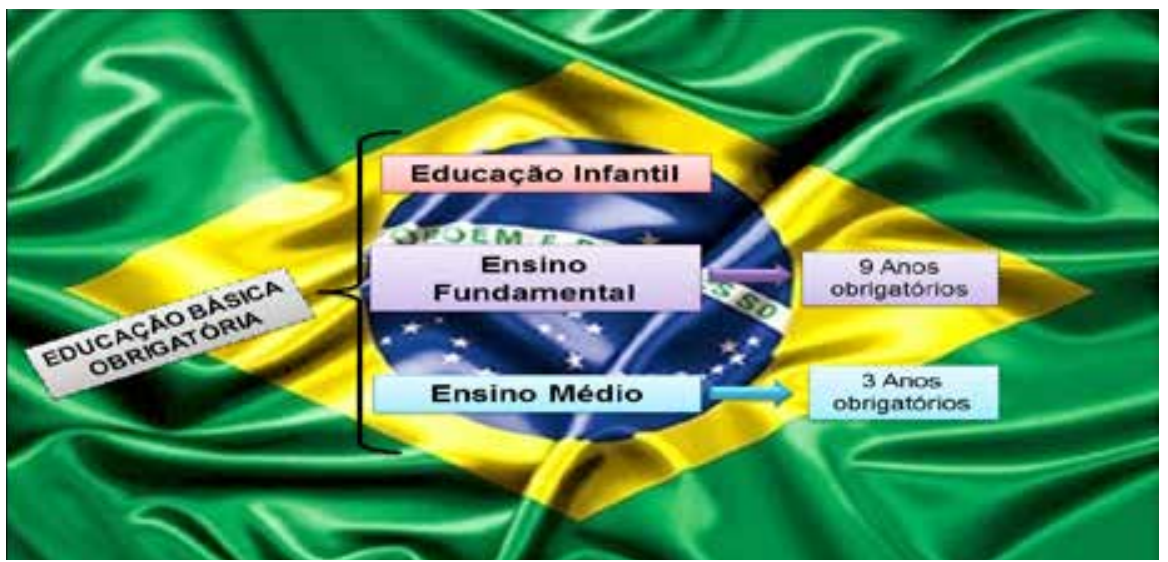

Fonte: Elaborada pelos pesquisadores com base em SILVA (2009).

Percebe-se na imagem anterior que a educação brasileira tem como obrigatoriedade para o sujeito o curso da Educação Infantil dos nove anos obrigatórios do Ensino Fundamental, sendo os primeiros cinco nomeados de anos iniciais e os últimos quatro chamados de anos finais. O Ensino Médio, como última etapa da Educação Básica, tem sido objeto de discussão em diferentes espaços (CORSO; SOARES, 2014), e esta pesquisa foca nesse grau de ensino, em que a Química legitima-se como componente curricular da área de Ciências da Natureza e suas Tecnologias. Nesse contexto da história curricular recente no Brasil, buscou-se, neste estudo, ouvir os professores brasileiros que atuam neste nível de ensino, visando a reconhecer o que os mesmos concebem por currículo, pois, para Silva (2006), analisar os currículos concretos significa estudá-los 
no contexto em que se configuram e pelo qual se expressam em práticas educativas. Assim, estudar o currículo, nesse contexto, significou adentrar nas Escolas Públicas de Ensino Médio de uma cidade do Sul do Estado do Rio Grande do Sul - RS - e conversar com os sujeitos que fazem o processo educativo e de ensino acontecer. Para isso, o objetivo geral desta pesquisa consistiu em: Reconhecer e interpretar o que os professores enunciam acerca do Currículo de Química na Educação Básica, em termos de concepções, discursos e práticas. Entende-se que é fundamental reconhecer também os significados históricos que contribuíram para constituir essa "rede de significação" (SMOLKA, 2004) do que seja este objeto - o currículo. Afinal, que Currículo de Química os professores consideram relevante e sobre quais critérios assenta-se a sua escolha? 0 que se concebe por currículo?

\section{METODOLOGIA}

Metodologicamente, o presente estudo apresenta-se com uma abordagem qualitativa, visando a produzir informações aprofundadas e ilustrativas sobre o currículo como objeto de estudo e pesquisa. De acordo com Gerhardt e Silveira (2009), a pesquisa qualitativa preocupa-se com aspectos da realidade que não podem ser quantificados, centrando-se na compreensão e explicação da dinâmica das relações sociais, imbricadas em determinada temática e contexto de estudo. Entende-se que se trata de um "Estudo de Caso" complexo, porque explora o caso do Currículo de Química em ação em determinado município, o qual contemplou os professores da rede pública Estadual desse município. Destaca-se que, de acordo com Gil (2010), um estudo de caso é um estudo exaustivo e profundo de um ou poucos objetos, de maneira que permita um amplo e detalhado conhecimento.

A produção de dados foi realizada por meio de entrevistas semiestruturadas com professores do perímetro urbano da cidade que se localiza no litoral sul do Estado e possui um total de 13 escolas de Ensino Médio, as quais atendem uma população aproximada de 208 mil habitantes (IBGE, 2010). Conforme já salientado, o método usado na produção de dados foi a entrevista, que Haguette (1997) define como um processo de interação social entre duas pessoas, na qual uma delas - o entrevistador - tem por objetivo a obtenção de informações por parte do outro - o entrevistado. A escolha pelas entrevistas semiestruturadas decorre da intencionalidade da entrevista em alcançar os objetivos, mas de forma aberta para o que possa emergir. O principal motivo deste zelo é a possibilidade de comparação com o mesmo conjunto de perguntas, cujas diferenças devem refletir aspectos relacionados às concepções dos respondentes e não diferença nas perguntas (LAKATOS; MARCONI, 1996). As entrevistas foram gravadas em áudio, transcritas e, em seguida, devolvidas aos sujeitos para a leitura prévia e autorização de uso com garantia de anonimato.

No Quadro 1 apresenta-se o roteiro da entrevista semiestrutrada com as seis questões norteadoras da conversa entre o pesquisador e os professores: 
Quadro 1 - Questões norteadoras da entrevista semiestruturada

$>$ Se você fosse convidado a pensar o Currículo de Química do Ensino Médio, quais seriam as suas recomendações/proposições?

D Quais metodologias poderiam ser contempladas nesse currículo que você iria propor?

$>$ Quais conteúdos disciplinares você considera importante e que não deveriam ficar de fora do Currículo de Química no Ensino Médio?

$>$ Além do que foi dito, o que mais o Currículo de Química deve contemplar?

$>$ Você já teve alguma experiência (alguma prática, atividade, etc.) proposta pelo currículo que você achou marcante por perceber resultados positivos no processo de ensino e aprendizagem dos estudantes?

$>$ Você pode contar mais sobre essa experiência marcante? Foi uma ou mais aulas? O que você fez nessa experiência? Foi proposto pelo Currículo da Escola?

Fonte: Elaborado pelos pesquisadores, 2018.

Todos os professores que aceitaram o convite de participação na pesquisa assinaram um Termo de Consentimento Livre e Esclarecido (TCLE), cuja cópia se encontra uma com o pesquisador e outra com o participante. Além dos TCLE, o pesquisador criou uma ficha de cadastro para cada professor participante, e essa ficou anexada nos TCLEs e serviu como meio para caracterização dos sujeitos, bem como forneceu os contatos dos pesquisandos para os responsáveis pela pesquisa. O modelo da ficha de cadastro pode ser visualizado no Quadro 2:

Quadro 2 - Ficha de cadastro dos participantes

\begin{tabular}{|lll|}
\hline \multicolumn{2}{|c|}{ PERFIL DO ENTREVISTADO } & \\
Nome: & Idade: & anos \\
E-mail: & Escola(s): \\
Regime de Atuação: $($ ) Contrato $($ ) Nomeação/Concurso & Tempo de Atuação: \\
\hline
\end{tabular}

Fonte: Elaborada pelos pesquisadores, 2018.

Após a realização das entrevistas, todos os participantes foram nomeados e organizados em uma tabela de arquivo no Software Microsoft Exce ${ }^{\circledR}$ (arquivo .xslx), e cada professor recebeu um codinome - o nome de um elemento químico - para mantê-lo no anonimato. A escolha deu-se aleatoriamente, porém tomou-se o cuidado para eleger elementos cuja simbologia foi representada por duas letras, para que, posteriormente, os professores fossem identificados por códigos, que correspondem aos símbolos dos elementos. A Figura 3 mostra o modelo de Tabela adotado para cadastro dos professores.

Figura 3 - Tabela de cadastro dos participantes

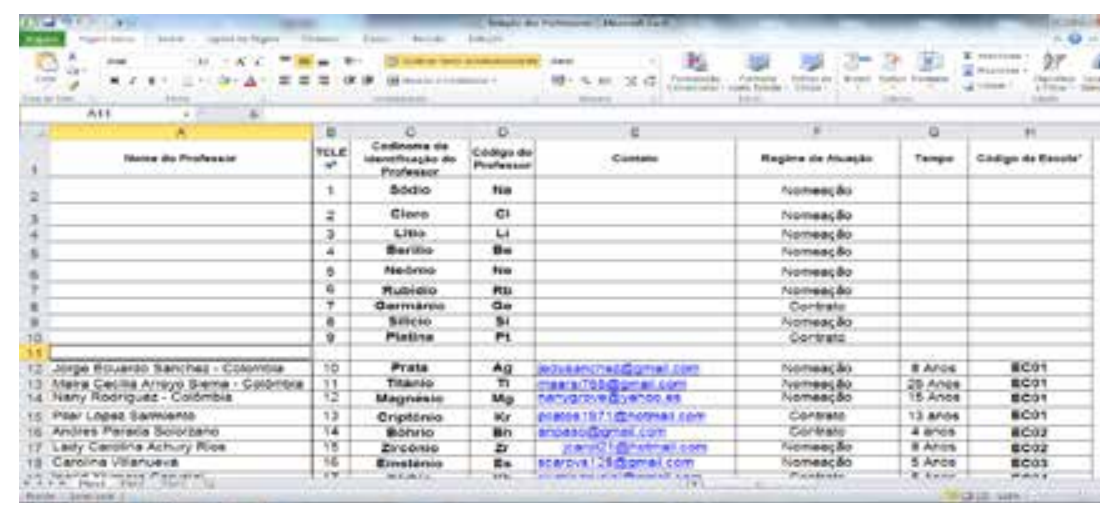

Fonte: Elaborada pelos pesquisadores, 2018. 
Percebe-se na Figura 3 que há na tabela um espaço (coluna A) para inserir o nome do voluntário, bem como o número do TCLE que ele assinou. Após, na coluna "C", há o espaço para o codinome do professor voluntário e, ao lado, o seu código, que se trata da simbologia do Elemento. Ainda é possível perceber na coluna " $\mathrm{H}$ " os códigos da escola onde o mesmo exerce suas atividades docentes, posto que EB refere-se à Escola Brasileira.

Para a análise dos dados usou-se a Análise Textual Discursiva - ATD -, que é uma metodologia de natureza qualitativa e que busca "descrever e interpretar alguns dos sentidos que a leitura de um conjunto de texto pode suscitar" (MORAES; GALIAZZI, 2011, p. 14). Cada entrevista transcrita faz parte do Corpus de análise da pesquisa para sua posterior "desmontagem". Moraes (1999) ressalta que este é o processo de unitarização e compreende três momentos: primeiro, faz-se as fragmentações e codificações de cada Unidade de Significado (US); segundo, a nucleação dessas USs, as quais levam à produção de categorias, e, por fim, a reescrita de cada US passa a assumir um significado mais completo no confronto com o referencial teórico, objetivando produzir metatextos para cada categoria. Uma das características da ATD é a elaboração e a organização de Categorias, que possuem elementos de definição e interpretação e que são apresentados e discutidos na forma de metatextos. Na apresentação dos resultados essas USs são apresentadas com os códigos dos professores, por exemplo: o currículo é uma forma organizada de dispor esses conteúdos e esses conceitos químicos ( $\mathrm{NaO2}$ ).

Mediante esse entrelaçamento do campo empírico com o teórico, pode-se reconstruir o sentido de currículo, como concepção, discurso e ação, por meio de categorias emergentes, com as marcas dos sujeitos, seus contextos sociais e históricos. Parte-se do pressuposto de que o currículo como um objeto em constante reconstrução, conforme Tanner e Tanner (1975), pode ser entendido como uma experiência de aprendizagem planejada e guiada e o resultado de aprendizagem não desejado, formulado por meio da reconstrução sistemática do conhecimento.

Para Sacristán (1995), o currículo é práxis, ou seja, uma ação concreta, que deve ser entendida como processo que envolve uma multiplicidade de relações, abertas ou tácitas, em diversos âmbitos, que vão dar prescrição à ação das decisões administrativas às práticas pedagógicas na escola como instituição e nas unidades escolares especificamente. Para compreendê-lo e, principalmente, para elaborá-lo e executá-lo de modo a transformar o ensino, é preciso refletir sobre essas grandes questões à luz do que enunciam os protagonistas do currículo - os professores, sujeitos dessa pesquisa -, conforme segue.

\section{RESULTADOS}

Do corpus das entrevistas, segundo os passos da ATD, alcançou-se um total de 177 unidades de significados (USs) que dialogaram com a questão central desta pesquisa, citada anteriormente. Todas as USs foram agrupadas/nucleadas em 22 categorias iniciais, que foram novamente reagrupadas e resultaram em 5 categorias finais, das quais optou-se por apresentar 3 neste artigo. Ao alcançarem-se as categorias finais, que são conceitos ou generalizações que resultam de processos de abstração do intelecto humano no exercício de suas funções (VYGOTSKY, 2001), foram criadas, para cada catego- 
ria final, proposições que "são afirmativas defendidas ao longo do texto com argumentos produzidos" (RITTER, 2015, p. 82), que serão apresentados nos metatextos junto com as discussões das unidades teóricas e das unidades de significados. Na Tabela 1 são apresentadas as três categorias finais com suas respectivas proposições.

Tabela 1 - Categorias finais e suas respectivas proposições

\begin{tabular}{|c|c|}
\hline Categoria final & Proposições \\
\hline 1. Currículo Inovador & $\begin{array}{l}\checkmark \quad \text { Proposição 1.1: os professores propõem um Currículo de } \\
\text { Química com conteúdos ligados ao cotidiano dos estudantes, mas } \\
\text { não parecem interpretar os fundamentos dessa decisão. } \\
\checkmark \quad \text { Proposição 1.2: o currículo "precisa" contemplar } \\
\text { metodologias diferenciadas. }\end{array}$ \\
\hline 2. Currículo Tecnicista & $\begin{array}{l}\checkmark \quad \text { Proposição 2.1: o Currículo de Química atual é concebido } \\
\text { como uma lista de conteúdos na qual o docente deve cumprir/ } \\
\text { ensinar. }\end{array}$ \\
\hline $\begin{array}{l}\text { 3. Currículo como } \\
\text { discurso/definição }\end{array}$ & $\begin{array}{l}\checkmark \quad \text { Proposição 3.1: o currículo deve se preocupar com a } \\
\text { formação do cidadão. }\end{array}$ \\
\hline
\end{tabular}

Fonte: Elaborada pelos pesquisadores, 2018.

\section{Primeira Categoria: currículo inovador}

O objetivo principal desta pesquisa centrou-se em conhecer as concepções enunciadas pelos professores. Nesse sentido, as falas sinalizam para um currículo "inovador"; daí a razão para ser nomeada essa categoria. O que, porém, afinal, é ser um currículo inovador?

Acredita-se que não se chega facilmente ao entendimento dessa questão, pois cada pessoa terá a sua ideia de inovador e isso será cruzado com as suas respectivas bases teóricas e epistemológicas. As duas proposições que seguem vêm no caminho de apresentar algumas das ideias que este currículo, dito inovador, pode contemplar.

Proposição 1: Os professores propõem um Currículo de Química com conteúdos ligados ao cotidiano dos estudantes, mas não parecem interpretar os fundamentos dessa decisão

Uma das concepções mais recorrentes nas falas dos docentes é a de que a química deve conversar com o cotidiano do estudante. Parece uma afirmação lógica e coerente, porém, ao interpretá-la, se vê indícios de que existe atualmente nas escolas de Ensino Médio um currículo descontextualizado e que foge da realidade dos sujeitos aprendentes. É consensual de que é quase impossível ensinar química longe da realidade do estudante, pois trata-se de uma Ciência que estuda a Natureza do mundo material, cujos fenômenos e conceitos manifestam-se no nosso dia a dia, contudo carece desse tipo de interpretação.

Demo (1994) deixa claro que a contextualização significa a vinculação do ensino com a vida do aluno, e Santos e Mortimer (1999) ressaltam que, muitas vezes, os termos "contextualização" e "cotidiano" são utilizados como sinônimos e isso acaba reduzindo o significado destes e, com isso, o seu entendimento. Wartha, Silva e Bejarano. (2013) apresentam trechos de documentos, como os PCNs, que evidenciam que a contextuali- 
zação não deve servir para a banalização dos conteúdos das disciplinas, mas, sim, como um recurso pedagógico capaz de contribuir para a construção de conhecimentos e formação de capacidades intelectuais superiores (BRASIL, 1999).

O uso da contextualização em sala de aula não deve banalizar para o uso exclusivamente do senso comum, mas é necessário que se adote a postura da segunda ruptura epistemológica proposta por Boaventura de Souza Santos (2000), na qual o senso comum é transformado com base nos conceitos científicos. Para Santos (2001), é preciso que os conhecimentos históricos das Ciências, fechados em si mesmos e de natureza abstrata, gerem novos significados na relação com os saberes oriundos da vida dos estudantes. Essa segunda ruptura epistemológica dá lugar a outro modo de construção de saberes, que relaciona os conhecimentos científicos e os avanços tecnológicos à estrutura social e cultural da comunidade onde a instituição de ensino está inserida. Somente "a abordagem de exemplos reais e/ou próximos do cotidiano dos alunos, por si só, não é o suficiente para conferir sentido a um ensino muitas vezes fragmentado" (PRUDÊNCIO, 2013, p. 38).

Tendo em vista este alerta, apresenta-se algumas das USs identificadas nas enunciações dos sujeitos que defendem uma abordagem da química ligada ao cotidiano dos estudantes:

A primeira delas, tu tirares alguns conteúdos de dentro do currículo, porque tem muitas coisas. Para o aluno do Ensino Médio é importante somente a parte que ele consiga contextualizar e trazer para a realidade dele (Be01 - grifos nossos).

Minha proposição seria esse currículo com base nas situações de estudos porque é uma forma do estudante significar esse conhecimento que é tão distante da vida dele... (Na01 - grifos nossos).

Para o professor Berílio, contextualizar é justamente associar o que é trabalhado em sala de aula com a sua realidade. Ou seja, esse professor, se fosse convidado a pensar um currículo, reformularia a listagem de conteúdos que, supostamente, regem as disciplinas de química nas escolas de Ensino Médio e pensaria apenas em conteúdos capazes de serem contextualizados com o cotidiano. É preciso relembrar, entretanto, que os conceitos trabalhados em sala de aula na disciplina de química têm seu valor científico embora sejam de natureza abstrata e por essa razão o professor sente dificuldade para contextualizar, até porque um conceito não é uma formação isolada, fossilizada e imutável (VYGOTSKY, 1998).

A ideia de uma ciência abstrata corrobora para a primeira ruptura epistemológica de Bachelard (1996), na qual a ciência será construída contra o senso comum, ou seja, em uma visão geral o senso comum que o estudante carrega das suas experiências vivenciais é visto como persona non grata para a ciência ensinada na sala de aula. Para Bachelard (1996), o rompimento com o senso comum foi uma condição para a evolução do conhecimento científico. Santos (2000), porém, ao referir-se ao ensino de Ciências, propôs a segunda ruptura epistemológica da ciência, sendo ela necessária para que se alcance um senso comum esclarecido e uma ciência prudente. Para o autor: 
A dupla ruptura procede a um trabalho de transformação tanto do senso comum como da ciência. Enquanto a primeira ruptura é imprescindível para constituir a ciência, mas deixa o senso comum tal como estava antes dela, a segunda ruptura transforma o senso comum com base na ciência (p. 41).

Compreende-se a segunda ruptura como importante, pois ela não irá descartar a "bagagem" do senso comum que o estudante traz, mas, sim, irá modificá-la com base nos conceitos científicos. Essa sugestão de Santos (2000) é na perspectiva da Teoria da Aprendizagem Vygotskyana, explicitada pela relação entre conceitos espontâneos e não espontâneos ou entre conceito cotidiano e conceito científico (VYGOSTSKY, 1998). Assim, a ciência em perspectiva de ensino deve retornar ao contexto para que os conceitos ganhem significados e o ensino gere aprendizagem e desenvolvimento.

Nessa abordagem histórico-cultural, um conceito de ciência estaria compondo um corpo ordenado de conhecimentos que pressupõe um sistema supra ordenado e subordinado, conforme Vygotsky (1998). Para o autor, cada conceito tem de:

[...] ser inserido em dois contínuos - um que representa o conteúdo objetivo e o outro que representa atos de pensamento que apreendem o conteúdo. A interseção dos dois determina todas as relações entre o conceito dado e os outros - seus conceitos coordenados, supra-ordenados e subordinados. Essa posição de um conceito no sistema total de conceitos pode ser chamada de sua medida de generalidade (p. 97).

Já na fala do professor Sódio está explícita uma concepção de proposta curricular que contempla a contextualização defendida pelo professor Berílio, e que se denomina Situação de Estudos (SE). As SEs compreendem uma proposta curricular de criação coletiva que é "conceitualmente rica, identificada nos contextos de vivência cotidiana dos estudantes fora e dentro da escola, sobre a qual eles têm o que dizer e, no contexto da qual, eles sejam capazes de produzir novos saberes expressando significados para tais saberes e defendendo seus pontos de vista" (MALDANER; ZANON, 2001, p. 53).

O uso de SE em sala de aula pode ser uma importante ferramenta de contextualização dos conceitos científicos, pois com ela aborda-se intencionalmente situações da vida real e concreta dos estudantes, em que se inserem os conceitos científicos para interpretar essas situações. A SE pode fazer com que os estudantes possam interagir mais intensamente com o professor e com o objeto de estudo, havendo a possibilidade de uma melhora da aprendizagem (MALDANER et al., 2001). Um dos aspectos defendidos para o uso de SE na educação básica, de acordo com Sangiogo et al. (2013), é sua permanente significação conceitual. Ainda, é importante destacar que o conceito pode ganhar novos significados à medida que é articulado a outras situações ou a outros contextos de discussão, nas interações em diferentes disciplinas escolares e SE (SANGIOGO et al., 2013).

Seguindo, é preciso destacar que para o professor Lítio um motivo para relacionar a química com a realidade do discente é para que ele a conceba como uma ciência que o cerca e que traz benefícios para a sua vida, como aponta a unidade de significado 01 desse professor: 
[...] eu acho que o interessante seria a Química trabalhada mais para o dia a dia, porque muitos alunos, em muitas vezes, não conseguem gostar de Química porque eles não percebem a utilização no dia a dia da Química, o quanto ela é importante e para que ela serve (Li01 - grifos nossos).

Assim, na visão de professores como a Platina, vivemos em uma época em que há uma formalidade do currículo e algumas intencionalidades que não são explicitadas.

Eu acho que está muito direcionada à formalidade e não à contextualização, então tem muito assunto, tem muito conteúdo, e tem pouca diversidade de aplicação (Pt03 - grifos nossos).

A questão formal, a que se refere a professora Platina, talvez esteja ligada às políticas de currículo que, supostamente, deveriam orientar e preparar os professores das escolas para a compreensão desses princípios curriculares defendidos nas últimas décadas, a exemplo da interdisciplinaridade e da contextualização. Há uma interpretação simplificada, principalmente para o professor que veio de uma formação que antecedeu a discussão desses princípios e pressupostos e que concebeu o currículo como "a listagem de conteúdos programáticos", e isso tem sido considerado uma das barreiras que impedem uma maior compreensão teórica e prática desses novos princípios e, por consequência, demanda um repensar do lugar da ciência nesse novo contexto; defende a relação, conceito e cotidiano, mas não são conhecidos os meios teóricos e práticos para efetivar tal relação e, por isso, está na fala dos professores a defesa por um maior vínculo da química com a realidade do educando. Por essa razão, segue um modelo ultrapassado, e a seguinte US reconhece a necessidade de "Uma mudança no modelo num todo, até porque o aluno que está chegando hoje em uma sala de aula, ele encontra a mesma sala de aula que eu encontrei há 40 anos" (Be06).

O pensar e (re) pensar o currículo promove uma ação reflexiva sobre como tem sido a ação docente de todos nós professores, em todos os níveis. É preciso que todos os sujeitos envolvidos no processo educacional se capacitem e não percam a sua capacidade reflexiva crítica de pensar as suas ações e respectivas consequências; isso passa por uma compreensão não apenas de princípios curriculares, mas também sobre epistemologia da ciência, psicologia da aprendizagem, dentre outras (RITTER, 2017). A proposição que segue avança nessa reflexão.

Proposição 2: O currículo "precisa" contemplar metodologias diferenciadas

Evidenciou-se a preocupação dos professores quando apresentam uma concepção de currículo como uma lista de conteúdo a ser trabalhada. Há professores que acreditam que o problema da aprendizagem dos estudantes pode estar relacionado à metodologia de ensino, sendo necessário repensar a prática pedagógica na sala de aula, como expresso nas seguintes USs:

Assim, a gente tem que mudar muito a parte de abordagem em sala de aula... (Ne01-grifos nossos).

A minha sugestão para o currículo na questão de conteúdos é manter os mesmos, porém a forma na qual eles estão sendo trabalhados é que eu mudaria (Pt01 - grifos nossos). 
Tanto para o professor Neônio quanto para a professora Platina, não é necessário repensar o currículo "como lista", mas, sim, as formas (metodologias) de trabalhá-lo em sala de aula. Os próprios docentes, quando começam a discutir metodologias que podem ser utilizadas em sala de aula, apresentam sugestões conforme as USs:

Eu gosto muito de observação de meio ambiente, então, por exemplo, tu está dando aula sobre funções, chuva ácida e tu vais observar estátuas na cidade. Tu mostras a corrosão, tu mostras o que está acontecendo, aí a própria reação química tu demonstras para eles. Então, a visualização eu acho muito importante (Cl08 - grifos nossos).

Um currículo que levasse em conta o histórico escolar do aluno dando uma importância a atividades práticas e atividades, dentro das possibilidades, fazendo o intercâmbio com os outros professores (Rb01 - grifos nossos).

...o que eu sempre vejo que é positivo e que funciona muito bem é a aula prática. $A$ aula experimental é sempre muito rica e eu sempre trabalho com esse tipo de aula... (Ge07 - grifos nossos).

A questão da aula prática é uma das coisas que eu mais faço porque tem muito significado para eles. A questão das informações, dos vídeos, dos debates, documentários... Todas essas metodologias são importantes (Si07 - grifos nossos).

É possível perceber e reconhecer, nas concepções dos professores, o desejo de realizar "algo diferente", mas que, também, dá indícios de concepção de ciência como algo que começa com a observação, com a experimentação, demarcando uma ideia de empirismo nas ciências (CHALMERS, 1993). Quando se fala no termo "empirismo" é preciso lembrar que essa foi uma teoria que afirmava que o conhecimento vem exclusivamente, ou principalmente, a partir da experiência sensorial; por exemplo, somente existirá química existindo, a priori, a experimentação. Para o empirista clássico, os verdadeiros fundamentos do conhecimento são acessíveis aos indivíduos por meio dos sentidos (CHALMERS, 1993, p. 154).

Mesmo que esteja presente a preocupação com as formas de ensinar, para o professor as atividades, como a "observação" e a "atividade prática", deveriam permear as aulas de Química. De acordo com Axt (1991), é dada pouca atenção para o potencial da experimentação como ferramenta auxiliar para a significação conceitual, e raras vezes ela é usada para apropriação de conceitos específicos. Vilela, Vasconcellos e Gomes (2005) salientam que a experimentação não fica restrita à presença concreta dentro da sala de aula da ilustração ou do que é acessível aos sentidos, e tanto o experimento realizado ao vivo quanto uma reconstrução história de experimentos clássicos podem auxiliar no processo de ensino. Assim, para Bueno et al. (2007), a função do experimento é fazer com que a teoria interprete a realidade. Este seria o sentido da experimentação - a significação -, que, muitas vezes, é pouco falada e buscada como intencionalidade pedagógica.

Obviamente não pode existir uma ideia preconcebida dos docentes como alguém que simplesmente não opera numa perspectiva inovadora de ciência e ensino, uma vez que essa intencionalidade existe e aparece em suas falas, nomeada como novas formas de ensinar. Existem, contudo, alguns fatores que dificultam o trabalho docente nessa perspectiva, conforme as USs identificadas na fala do professor Berílio e do professor Lítio. 
Então essas metodologias a gente até pensa, a gente faz, mas daí pega no lado do grande número de alunos que nós temos na sala de aula, pega também na falta de tempo que o professor tem para preparar e organizar essas aulas, mas eu sigo batendo o martelo que é impossível fazer (Be09-grifos nossos).

Muitas vezes aqui na escola nós temos vontade, sim, de fazer certas aulas práticas, mas, nós temos diversos obstáculos. Nós temos um laboratório que poderia estar funcionando diariamente, mas, dependemos de vários recursos, dependemos de monitor, de reagente, de material, de vidraria. Então, a gente acaba barrando e aí nós temos vários empecilhos... (Li07 - grifos nossos).

O que é enunciado como "obstáculo", prático como o tempo - a lotação das salas de aula -, é também "obstáculo epistemológico", e Lopes (1999) ensina que é importante "se compreender os aspectos epistemológicos e sociológicos associados aos problemas educacionais de uma forma mais ampla" (p. 17). Muito das concepções que os docentes carregam consigo sobre este instrumento está relacionado com o seu entendimento epistemológico de ciência, conforme explicitou Carvalho (2006):

[...] a resistência às mudanças tem-se mostrado ligada às concepções epistemológicas dos professores sobre a natureza das ciências, que ensinam, de suas concepções alternativas sobre o ensino e a forma como os alunos aprendem (p. 22).

Percebe-se nas USs algumas das dificuldades que surgem como um empecilho para aquilo que o professor entende pertencer ao campo das metodologias alternativas, mas que também podem ser interpretadas como concepção de Ciência e ensino de Ciência experimental. "Perpetua-se, assim, uma química ancorada pela verificação, ilustração e experimentação, com uma crença de que é necessário ver para compreender" (RITTER-PEREIRA, 2011, p. 27).

$\mathrm{Na}$ fala do professor Berílio, percebe-se que há nas salas de aulas das escolas públicas brasileiras um grande número de alunos, tornando inviável a utilização, de, por exemplo, laboratórios. Não se fundamenta, contudo, a razão pela qual a experimentação é capaz de dar significado à linguagem científico-escolar, posto que as "aulas experimentais de química visam muito mais ao espetáculo do que à reflexão mais profunda a dar sentido aos conceitos que se quer significar" (RITTER-PEREIRA, 2011, p. 27). Na linha científica intitulada de empirista positivista, que está enraizada em Francis Bacon, é aceito que a experimentação controlada é a única forma de estudar e conhecer a natureza (MALDANER, 2001) e, de uma forma ou outra, somos todos herdeiros dessa tradição de ensino e desse modo de conceber a Ciência.

Claro que não se pode desconsiderar que, em razão do grande número de estudantes nas aulas, o atendimento no laboratório fica praticamente inviável. Percebe-se nas escolas que os reagentes que acabam excedendo a sua vida útil, vidrarias e materiais que vão se deteriorando, permanecem em desuso com o passar do tempo. Tais fatos evidenciam, no mínimo, dois motivos para o não uso desses reagentes, quais sejam, compreender sua real função e o seu significado no currículo, sendo que isso irá gerar argumentos em relação à falta de espaço e tempo.x Da mesma forma, é preciso ressaltar que, muitas vezes, a estrutura laboratorial não é usada, mas não pela falta de vonta- 
de do professor e, sim, pela falta de recursos teóricos que fundamentem sua prática nos três níveis do conhecimento (MORTIMER; MACHADO; ROMANELLI, 2000; JOHNSTONE, 1982; MELO, 2015).

São três os aspectos do conhecimento: fenomenológico, teórico e representacional. O primeiro aspecto - fenomenológico - "se refere aos aspectos visíveis e concretos, como a efervescência de um comprimido, a combustão de uma vela, além de outros que podem ser percebidos indiretamente, como, por exemplo, a produção de pães e bolos em uma confeitaria" (MELO, 2015, p. 19). Ainda, de acordo com Melo (2015), o segundo aspecto - teórico - abrange as explicações de natureza essencialmente abstratas e baseadas em modelos. É como a Ciência explica determinado fenômeno, utilizando conceitos, por exemplo, de átomos, moléculas, íons, dentre outros. Por fim, o nível representacional abarca as representações por meio da linguagem científica, utilizando-se de equações, fórmulas, gráficos e símbolos (MELO, 2015). Nessa concepção, espera-se que o professor possa criar estratégias, como levar um experimento para a sala de aula e provocar discussões demonstrativas, porém não ficando apenas na demonstração, mas inserindo conceitos que possam interprestar o fenômeno e, com isso, ganhar níveis sempre mais elevados de significação. Por que, todavia, não o faz? Provavelmente porque não consegue reconhecer os motivos e as reais necessidades de articular os três aspectos do conhecimento (MORTIMER; MACHADO; ROMANELLI, 2000), muito embora reconhecidamente existe a condição de um excessivo número de alunos em salas de aulas, conforme aponta Pintoco (2017).

Assim, em muitos estabelecimentos de ensino, o número de alunos em sala de aula é elevado, não considerando as condições e características regionais e locais da escola. É importante questionar a metodologia da política educacional que estabelece um número sem consultar os profissionais especializados na questão e que trabalham no dia-a-dia em sala de aula. Seria equivalente, embora mais subjetivo, que estabelecer uma portaria sobre o tempo que um doente deve ficar no hospital, sem consultar os médicos. Mas como definir um número adequado de alunos em sala? (p. 14).

Seriam necessárias políticas públicas visando a discutir os motivos de práticas curriculares cristalizadas e/ou incentivo às atividades práticas em escolas com, por exemplo, contratação de técnicos ou monitores que ficariam responsáveis por preparar os materiais do laboratório para o uso pelo professor e pela turma de alunos. Mais que isso, ainda, é preciso, também, repensar as políticas de formação continuada de professores atrelada às críticas referidas à qualidade de ensino nas salas de aula da Educação Básica brasileira.

É urgente e desafio inadiável dos gestores da educação brasileira definir políticas de formação continuada para esses professores que estão em sala de aula. Afinal, dificuldades de abordagem são diretamente relacionadas às dificuldades de compreender a própria ciência e seu corpo de conhecimentos. Nessa direção, alinha-se o que é uma boa abordagem dos conceitos específicos em salas de aulas e a utilização de metodologias diferenciadas, contribuindo, assim, para uma melhora do processo de ensino e aprendizagem num todo. 


\section{Segunda Categoria: currículo tecnicista}

Ao contrário das concepções de um currículo inovador, há concepções mais clássicas dos docentes voltadas a um currículo mais tradicional, que retratam uma vertente tecnicista. Mesmo com a existência dessas concepções, Matui (1988) faz uma leve crítica a esta forma de enxergar o currículo, uma vez que, de acordo com o autor, uma escola tecnicista desenvolve uma teoria de aprendizagem que torna o aluno apenas um depositário passivo dos conhecimentos. Esses currículos, conforme Luckezi (1994), possuem conteúdos de ensino sistematizados nos manuais, nos livros técnicos e didáticos, nos módulos de ensino e nos dispositivos audiovisuais. $\mathrm{O}$ docente precisa desenvolver essas atividades com base nos programas e nos manuais didáticos elaborados por outros, ou seja, nessa visão de currículo os professores não participam das decisões curriculares (SILVA, 2016).

Nesse entendimento, o currículo torna-se apenas a organização dos conteúdos que serão ensinados, ou meramente uma lista. Dessa forma, ao longo de estudos voltados à educação essa visão tecnicista vem perdendo força e dando lugar a novas abordagens, como o currículo inovador, dentre outros. Dentro dessas abordagens diferenciadas, surge a ideia de um currículo inovador, mas afinal: 0 que seria esse "inovador" a contrapor-se ao "tecnicismo clássico"? Para Masseto (2011):

[...] uma inovação curricular parte de sua Contextualização na Sociedade Contemporânea: procura identificar os novos cenários históricos, políticos, culturais; as ciências e a tecnologia nesse mundo; os valores e problemas que assolam as comunidades de adultos, de jovens, de crianças nas próximas décadas, no Brasil e no mundo (p. 16).

É preciso destacar que, de acordo com Senge (1996), para que exista a inovação é preciso um compromisso entre os que estão envolvidos no projeto de mudança, pois inovação e mudança andam juntas, mas somente acontecem, de fato, quando as pessoas nelas envolvidas se abrem para o processo, ou seja, para ter-se "inovações curriculares" é necessário que todos os agentes envolvidos na produção e execução deste Currículo de Química estejam empenhados no processo.

Evidentemente, não avaliamos e nem julgamos como certas ou erradas as concepções dos professores, posto que muitas de suas concepções vêm de suas trajetórias docentes e, até mesmo, de sua formação acadêmica, e que vão incorporando novos discursos/concepções e práticas. Faz-se necessário, contudo, discutir a vertente que os constituiu para vislumbrarmos novas trajetórias. A proposição que segue originou-se das falas que deixaram implícita a ideia de uma "lista" ou listagem.

Proposição 1: O Currículo de Química atual é concebido como uma lista de conteúdos na qual o docente deve cumprir/ensinar

O debate histórico da (re) construção do currículo no Brasil e no mundo faz-nos voltar ao debate do currículo com viés capitalista, descrito por Bobbit em sua obra de 1918, o qual concebia o aluno como uma mercadoria preparada pelo funcionário da indústria: o professor. Essa visão mais tradicional, preocupada em como fazer o currículo, foi defendida fortemente até meados de 1980 (SILVA, 2009), e aos poucos foi perdendo 
forma ante a uma tendência dita "inovadora" que, de acordo com Ramos (2011), incorporou uma proposta de currículo que transita "entre o avanço conceitual da relação entre trabalho, ciência e cultura, e a retificação de atividades e métodos ativos para tornar o currículo interessante aos estudantes" (RAMOS, 2011, p. 772).

Em boa medida somos tributários dessa visão tecnicista de currículo, que se manifesta, mesmo no século 21 , como meramente uma lista, como mostra as US a seguir.

Uma lista de assuntos que tu tens que enfiar no aluno. Esse é o meu conceito! Aí eu vou te dizer como eu faço; Eu faço isso? Normalmente não, às vezes eu não consigo cumprir o programa, mas, porque eu prefiro dar o conteúdo e ser direito, do que dar um conteúdo e simplesmente cumprir. Então, é uma coisa meio que enfiada goela abaixo (Cl09- grifos nossos).

Mas, eu acho que a gente sempre que faz aquelas reuniões e eu coloco aqueles nomezinhos, que acho que precisamos trabalhar isso no 1 , no $2 \circ$ ou no 30 ano, eu não me asseguro muito naquela listagem. (Be17 - grifos nossos).

...o Currículo de Química é o que a gente deveria ver nos anos que a gente tem, seja no Ensino Médio ou no finalzinho do Fundamental; ele é a parte de conteúdo a serem abordados (Ge02 - grifos nossos).

Percebemos na fala do professor Cloro a concepção técnica de um currículo como conteúdos que devem ser trabalhados, como programa a ser cumprido, e que vem "enfiada goela abaixo". O que parece desta fala é que há uma relação de poder institucionalizado, no qual o professor deve seguir as ordens de "superiores", internas ou externas à escola, e vencer os conceitos da listagem imposta por essa ordem, tal qual é a concepção do professor Berílio.

Tanto na fala do professor Cloro comoquanto na US identificada na fala do professor Berílio, há indício de que o docente não tem a visão do currículo em ação, mas, sim, somente uma visão do currículo apresentado aos professores. O currículo, muitas vezes, foi entendido apenas como o "conjunto de conhecimentos ou matérias a serem superadas pelos alunos dentro de um ciclo" (SACRISTÁN, 2000, p. 14). Há, ainda, de acordo com Sacristán (2000), a ideia do currículo como programa de atividades planejadas, devidamente sequencializadas, ordenadas metodologicamente e, também, a ideia de que esse artefato seja os resultados pretendidos de aprendizagem (SACRISTÁN, 2000). Quando se reconhece-se as US's anteriores, há uma impressão de que os docentes não se sentem atores principais na construção do currículo, apenas coadjuvantes que colocarão em prática o proposto pelos superiores (governo, escola, ...). Entendemos que o docente precisa ter autonomia na construção deste artefato, pois, a autonomia, não é uma capacidade individual, mas, sim, um exercício, uma prática social (CONTRERAS, 2002);, além disso, autonomia não deve ser entendida apenas como uma definição, mas e sim como uma ação.

Entendemos que o professor deve ser agente ativo na proposição do currículo e participar da seleção de conteúdos e metodologias que serão abarcados pelo artefato, visto quepois o currículo sempre parte de uma tradição seletiva, da seleção de alguém, da visão de algum grupo de conhecimento legítimo (APPLE, 1999), e, logo, entendemos 
da necessidade de que, quem faça essa seleção seja o professor, pois, é ele que colocará o currículo em ação nas salas de aulas, e, além do mais, é o docente que detém o conhecimento específico da sua disciplina.

Percebe-se, também, que o pensamento do professor Berílio e do professor Germânio são semelhantes, ou seja, têm-se a ideia de uma lista de conteúdos que precisa ser trabalhada na disciplina de química sem compreender razões, motivos e significados.

Ao analisar-se as falas docentes, emerge a ideia de um currículo técnico, como uma listagem de conteúdos, mesmo que estejamos vivendo em uma época de emergência de novas propostas curriculares e de autoria na proposição de currículo, como defende-se na LDBEN/1996. Existem vertentes que criticam um currículo com viés tecnicista justamente por enxergar o estudante como um "depósito" de conhecimento e o professor como alguém que segue o currículo definido fora de seu contexto de trabalho. Saviani (2007), por exemplo, irá afirmar que a pedagogia tecnicista, ao transpor para a escola "a forma de funcionamento do sistema fabril, perdeu a especificidade da educação, ignorando que a articulação entre escola e o processo produtivo se dá de modo indireto e por meio de complexas mediações" (SAVIANI, 2007, p. 16).

Para Andréa Villela Mafra da Silva (2016), no modelo tecnicista de educação a exigência da produtividade do sistema de ensino, por intermédio da racionalização, propôs objetivos de ensino fragmentados, capazes de prejudicar a qualidade da educação ( $p$. 206). A visão tecnicista pode ser entendida, de uma forma capitalista, como o professor "fabricando" a mão de obra. Segundo Frigotto (1984, p. 169), "A visão tecnicista da educação responde duplamente a ótica economicista de educação veiculada pela teoria do capital humano e constitui-se, a nosso ver, numa das formas de desqualificação do processo educativo escolar".

Em contraposição ao modelo Tecnicista, insere-se, por meio da LDB/1996, a discussão da autonomia docente como alguém que é capaz de produzir currículo (MALDANER; RITTER, 2014). Logo, pode-se entender que nessa visão técnica há uma grande preocupação com o viés econômico e com o preparo de bons profissionais e não, necessariamente, cidadãos capazes de enfrentar o mundo, remetendo-nos àquele currículo capitalista apontado por Bobbit em 1918, e que ainda permanece nas concepções docentes.

Em algumas falas docentes percebe-se uma ideia de que o currículo é aquela lista de conteúdo na qual o docente deve mergulhar ao longo do ano e vencer para que possa determinar se o estudante está apto a avançar, aprovando de ano ou não.

Eu acho que a gente tem que ter essa listagem para nós nos guiarmos, mas o profissional que está trabalhando é quem vai conduzir isso da melhor maneira... ( $\mathrm{NeO2}$ - grifos nossos).

Então a gente também não pode considerar o currículo como algo essencial. Para mim o currículo é como se fosse uma estrutura norteadora, só para mim me situar no que eu posso trabalhar (Be18 - grifos nossos).

Eu acredito que currículo seja um conjunto de medidas que tu vais trabalhar em sala de aula, na questão de conteúdos, questões de metodologias (Si05 - grifos nossos). 
...o currículo só tem a função do professor não ficar sem rumo, sem saber o que fazer... (Be19-grifos nossos).

Mesmo com alguns docentes apresentando essa concepção da simples e pura lista de conteúdos, alguns docentes, como o professor Lítio, vão na contramão:

...currículo, na verdade, é um conjunto de todas as atividades trabalhadas em sala de aula e não somente o conteúdo, mas, também, a maneira como é trabalhado aquele conteúdo, a abordagem como tu faz a avaliação em sala de aula, a maneira como tu explicas... (LiO3 - grifos nossos).

Currículo é tudo que pode desenvolver no meu educando a capacidade de lidar com aquele conhecimento (Pt02).

Percebe-se a existência de diversas concepções sobre o currículo na mente dos professores, mas que convergem para o argumento da necessidade de criar espaços e condições para a formação contínua. Esse modo de conceber o currículo explica os diversos aspectos elencados pelos professores, como cotidiano, metodologias, avaliação, entre outros, e algo tem sido consensual: Como é possível despertar no estudante o desejo? Para isso, manifestam preocupações acerca da forma como lidar com o conhecimento ensinado nas salas de aulas das escolas públicas brasileiras.

\section{Terceira Categoria: currículo como discurso/definição}

Nas concepções apresentadas pelos professores percebe-se que eles trazem, em seus discursos, um anseio de que a educação química se preocupe com o futuro cidadão que hoje está dentro da sala de aula como educando.

Nessa visão, a proposição a seguir remete à ideia de currículo com viés social e cultural, ou seja, ter uma preocupação com o sujeito que estamos "formando".

\section{Proposição 1: O currículo deve preocupar-se com a formação do cidadão}

Será que os professores têm refletido que o aluno que hoje está dentro das escolas de Ensino Médio em breve será o cidadão que estará na universidade, no mercado de trabalho e nos demais segmentos da sociedade? Muitas vezes a prática docente cai em uma rotina cansativa de ano após ano, e os docentes vão parando de refletir sobre o aluno que tem acompanhado as suas aulas. Estamos, às vezes, deixando de enxergá-lo como cidadão inserido nas suas comunidades e os vemos apenas como o aluno nota 10 ou com conceito " $A$ ". Deve-se destacar que a

[...] ciência contemporânea rompe as barreiras historicamente construídas entre os diferentes campos do conhecimento, superando os limites estreitos das especializações, construindo novas áreas a partir da integração de objetos e não na consciência, mas na vida social e produtiva (KUENZER, 2002, p. 86).

Ainda, cabe às escolas "desempenharem com qualidade seu papel na criação de situações de aprendizagem que permitam ao aluno desenvolver as capacidades cognitivas, afetivas e psicomotoras relativas ao trabalho intelectual" (KUENZER, 2002, p. 18). 
De outra parte, muitos educadores ouvidos apresentam essa preocupação, alinhando-se aos Parâmetros Curriculares Nacionais - PCNs (BRASIL, 2002) -, que sugerem o ensino e a organização do currículo nas escolas com foco na construção do conhecimento por parte do aluno e o desenvolvimento de competências necessárias para que o mesmo seja capaz de intervir e de entender a realidade, ou seja, o aluno deve mobilizar os conceitos aprendidos em sala de aula na resolução de problemas reais.

Na publicação dos Parâmetros Curriculares Nacionais para o Ensino Médio - PCNEM - em 1999 pelo Ministério da Educação Brasileira (BRASIL, 1999), o ensino de química contrapõem-se ao que entendemos como tradicional, quando o professor aplica os conceitos em sala de aula, o aluno "aprende", faz a avaliação e acaba esquecendo o que aprendeu, alcançando uma mísera aprendizagem descartável (FERNANDES, 2011). Fernandes (2011) salienta que a aprendizagem descartável é aquela que tem sua base nas "regrinhas", nas equações para decorar e nas demais técnicas utilizadas com essa finalidade, porém isso, após o término do estudo, acaba esquecido, ou seja, descartado.

Uma educação que se preocupa com o cidadão da sociedade de amanhã "se contrapõe à velha ênfase na memorização de informações, nomes, fórmulas e conhecimentos como fragmentos desligados da realidade dos alunos" (BRASIL, 1999, p. 87); assim, essa será uma importante contribuição para a almejada formação do cidadão. Estaríamos pensando uma educação para a cidadania?

Fica claro no artigo 205 da Constituição Federal Brasileira de 1988 que

A educação, direito de todos e dever do Estado e da família, será promovida e incentivada com a colaboração da sociedade, visando ao pleno desenvolvimento da pessoa, seu preparo para o exercício da cidadania e sua qualificação para o trabaIho (BRASIL, 1988, grifo nosso).

Assim, esse "compromisso" fica reiterado em algumas USs:

...nós aqui temos essa missão que é a de formar cidadãos... (Li15 - grifos nossos).

E eu acredito que o professor tem esse papel, pois ele pode levar o aluno a buscar as suas vocações e enquanto cidadãos eu acredito que nós temos um papel fundamental (Rb10 - grifos nossos).

...mas tu és obrigado a aprender, a correr atrás porque é um comprometimento, tu escolheste ser professor e quando tu escolhes ser professor, tu escolhe ser responsável pela formação das pessoas, então que essa seja a melhor possível (Cl07 - grifos nossos).

Fica evidenciado que o discurso docente vem sendo alinhado com o discurso proferido pelas políticas públicas da educação brasileira. Na 15a US o professor Lítio evidencia que a sua preocupação em formar cidadão não é só um objetivo e sim uma missão, e nesse processo o docente é capaz de orientá-lo aos caminhos a serem seguidos para que o cidadão encontre o seu papel e, assim, seja capaz de contribuir para a sociedade, como explanou o professor Rubídio. Libâneo (1996) destaca que o papel do educador merece atenção, uma vez que seu trabalho consiste, de modo geral, em preparar discentes para a vida social. Sendo assim, essa atividade humana deve ser considerada necessária à existência e funcionamento de todas as sociedades. Esse pensamento do docente Rubídio vem conversar com o que escreveram Santos e Schnetzler (2014): 
Considerando que a cidadania se refere à participação dos indivíduos na sociedade, torna-se evidente que, para o cidadão efetivar sua participação comunitária, é necessário que ele disponha de informações que estão diretamente vinculadas aos problemas sociais que afetam o cidadão, os quais exigem um posicionamento quanto ao encaminhamento de suas soluções (p. 46 - grifos nossos).

Nessa perspectiva, os professores entendem que a química pode, sim, contribuir na formação do cidadão, posto que ela é a chave para uma grande parte das preocupações do futuro da humanidade (NEWBOLD, 1987). O aluno usa em sala de aula conceitos científicos, porém eles podem e entendemos que devem ser vinculados aos problemas sociais que estão do lado de fora da escola. Questiona-se, entretanto: Como se faz isso? Ou melhor, essa relação da Ciência, por meio da linguagem científica para interpretar o mundo material e os fenômenos, foi superficialmente mencionada pelos professores. Essa ausência demonstra uma apropriação por parte dos professores do argumento de constituir cidadão, mas não demanda ações concretas de como se faz isso por intermédio de uma Ciência como auxiliar para interpretar o real. Os discursos certamente manifestam-se na produção de um documento que é a expressão dessas necessidades e que a escola foi chamada a produzir - o Projeto Político Pedagógico (PPP) -, e neste documento essas expressões "formação para a cidadania" estão sempre presentes, orientadas pelas normativas como LDBEN, PCNs, Diretrizes, dentre outros.

Reafirma-se que nessa escrita não se tem o foco de discutir o que é o papel em si da cidadania na concepção e prática curricular, mas, sim, apresentar que os professores das escolas públicas têm a concepção de que um currículo deve ter a preocupação de formar o futuro cidadão. É preciso deixar evidenciado que há uma relação entre educação e cidadania. Segundo Arroyo (1988), fica claro que essa relação ocorre no "sentido de que a luta pela cidadania, pelo legítimo, pelos direitos, é o espaço pedagógico onde se dá o verdadeiro processo de constituição do cidadão" (ARROYO, 1988, p. 79), sempre considerando a recomendação de Santos e Schnetzler (2014), que afirmam ser necessário adotar uma postura crítica na relação da educação com a formação da cidadania. Não se mostram tão evidentes, entretanto, ações pedagógicas com essa intencionalidade explícita e relacionada a alguma vertente de origem, a exemplo dos estudos CTS. A formação para a cidadania ficou centrada no campo do discurso!

Quando se faz essa conexão do ensino para formação do cidadão, surge, nas concepções dos professores, uma relação vaga com o conceito de Ciência, Tecnologia e Sociedade, como nas USs reconhecidas das falas dos professores Silício e Germânio:

...a gente não está aqui só para explicar conteúdo, mas estamos aqui para formar cidadãos para que eles saiam daqui sabendo fazer as coisas. Então em todas as disciplinas a Ciência, Tecnologia e Sociedade deveriam ser trabalhadas (Si13 - grifos nossos).

...dá para ti trabalhar justamente essa relação com a sociedade, fora da escola, do que isso poderia gerar de algo ruim, de impacto ambiental, e tudo isso dá para ti abordar dentro da Química e não só pegar aquela parte conteudista, porque tem esse enfoque CTS também, é claro (Ge06 - grifos nossos). 
Nas USs anteriores fica clara uma aproximação do currículo com conceitos teóricos debatidos por pesquisadores dedicados à investigação e à prática em abordagem CTS, que é um movimento que, de acordo com Santos (2011), tomou forma nas últimas décadas e têm se mantido ativo. O movimento da educação CTS não é a mera discussão da ciência e da tecnologia (C\&T) inseridas no contexto social, mas a efetiva articulação entre ambas, o que se dá a partir de três parâmetros apresentados por Strieder (2012, p. 176): “(i) Racionalidade Científica, (ii) Desenvolvimento Tecnológico e (iii) Participação Social". (STRIEDER, 2012, p. 176)

Esse movimento tem contribuído para que a educação científica se consolide no propósito de uma formação para a cidadania e, também, se torne um caminho ou meio para a recontextualização dos conhecimentos científicos escolares, conforme discutido anteriormente. Muito pouco desse debate, contudo, parece chegar até os professores imersos nos seus universos de sala de aula, lotada e com fragilidade de formação continuada e planejamento coletivo. Esse debate dos fundamentos CTS para pensar o ensino de Ciências também demarca a necessidade de debates acerca da epistemologia das ciências, e concepções sobre como se aprende ciência no contexto atual de revolução científica e tecnológica.

Pensar-se no movimento CTS é compreender que um currículo que tem esse foco vai além de associar conceitos científicos ao cotidiano dos estudantes, e tem a preocupação na formação de um cidadão crítico, capaz de desenvolver o pensamento químico sobre os fenômenos que o cercam no seu cotidiano, qualificando seu processo de tomada de decisão, desenvolvendo-se integral e harmonicamente com o meio.

\section{CONCLUSÕES}

Espera-se ter chegado ao limiar deste complexo campo de pesquisa: as concepções e práticas curriculares. Os resultados deste estudo deram indícios de que é possível avançar muito mais nas práticas curriculares em ação, território ainda pouco explorado no âmbito das Ciências Naturais. Esperamos, no entanto, ter contribuído com esse campo de pesquisa quanto ao reconhecimento do que pensam os professores sobre o Currículo de Química na Educação Básica em termos de concepções, discursos e práticas. Conheceu-se um pouco de suas concepções por meio do que os docentes enunciam e concebem como currículo, bem como a forma como colocam em prática este instrumento.

Por meio do processo de Análise Textual Discursiva obteve-se alguns indícios sobre as concepções que os professores trazem de sua formação e constituição, com marcas de um currículo tecnicista, porém constituindo uma amálgama com outras intencionalidades. Essa amálgama certamente é originária do discurso das políticas de currículo e das pesquisas em educação que estão em curso no Brasil, a exemplo da defesa pela contextualização e formação de cidadãos críticos, e que se mesclam com concepções já rotinizadas.

Nesse sentido, reconheceram-se concepções relacionadas com a necessidade de um currículo inovador, por meio do reconhecimento à necessidade de relacionarem-se em sala de aula os conteúdos científicos com o cotidiano do estudante, bem como se argumentou em favor de que o Currículo de Química contemple metodologias diferen- 
ciadas de trabalho em sala de aula. Ou seja, percebeu-se que ao tempo que existem concepções de um currículo inovador, existem discursos e práticas que se contradizem à inovação, a exemplo das chamadas "listas de conteúdos". Enfim, para os docentes o Currículo de Química pode ser uma lista de conteúdos, mas também para eles um bom Currículo de Química em ação deve preocupar-se com princípios como a contextualização, como enunciada nos documentos oficiais, bem como se preocupar com a formação do cidadão. A voz dos professores, sujeitos da pesquisa e que fazem o currículo acontecer, existe e tem se mesclado ao que vem sendo definido e concebido neste campo de conhecimento: o currículo.

Existem diversas pesquisas na Educação em Ciências teorizando acerca do currículo ou das políticas curriculares, mas poucas, ou raras vezes, os atores principais (professores) são ouvidos sobre sua concepção e prática, de modo que o currículo em ação ainda se mostra pouco explorado/interpretado. Assim, fez-se importante ouvir o que os atores principais do currículo em ação pensam e concebem sobre este artefato, assim,e conclui-se que os docentes trazem concepções construídas ao longo de suas caminhadas teóricas, epistemológicas e profissionais.

Os professores brasileiros de Rio Grande estão, de certa forma, alinhados com o "padrão" indicado pelas políticas nacionais da educação, apresentando uma preocupação com a formação de um cidadão crítico, e não apenas de um estudante que passe de ano e conclua os seus estudos. Além disso, há a proposição por parte dos professores de um currículo que contemple conteúdos ligados ao cotidiano dos estudantes, porém eles não parecem interpretar os fundamentos dessa escolha. Sendo assim, o professor rio-grandino posiciona-se a favor de contextualizar os conceitos da sala de aula com a vida do estudante, sendo que isto será adotado como uma forma de facilitar o processo de aprendizagem. Ainda, percebeu-se, na fala dos professores, que ser professor, especialmente no Brasil, exige a superação de barreiras, como aà falta de estrutura, de tempo, formação, dentre outras coisas.

\section{REFERÊNCIAS}

APPLE, Michael. Políticas culturais e educação. Porto: Porto Editora, 1999.

ARROYO, M. G. Educação e exclusão da cidadania. In: BUFFA, E.; ARROYO, M. G.; NOSELLA, P. Educação e cidadania: quem educa o cidadão? 2. ed. São Paulo: Cortez, 1988.

AXT, R. O papel da experimentação no ensino de Ciências. In: MOREIRA, M. A.; AXT, R. Tópicos em ensino de ciências. Porto Alegre: Sagra, 1991.

BACHELARD, G. O novo espírito científico: contribuição para uma psicanálise do conhecimento. Tradução Estrela dos Santos Abreu. Rio de Janeiro: Contraponto, 1996.

BRASIL. Constituição da República Federativa do Brasil. Brasília: Senado Federal, 1988.

BRASIL. LDB. Lei № 9.394, de 23 de dezembro de 1996. Diário Oficial da República Federativa do Brasil, Brasília, 1996.

BRASIL. Ministério da Educação. Parâmetros Curriculares Nacionais para o Ensino Médio. Brasília: MEC; Semtec, 1999.

BRASIL. Ministério da Educação. Parâmetros Curriculares Nacionais + $(P C N+)$ - Ciências da Natureza e suas Tecnologias. Brasília: MEC, 2002.

BRASIL, Ministério da Educação. Diretrizes Curriculares Nacionais do Ensino Médio - DCNEM. Brasília: MEC, 2012.

BRASIL. Ministério da Educação. Planejando a próxima década. Conhecendo as 20 metas do Plano Nacional de Educação. Brasília, DF: Ministério da Educação (MEC); Secretaria de Articulação com os Sistemas de Ensino (Sase), 2014. 
BUENO, L.; MOREIRA, K. C.; SOARES, M.; WIEZZEL, A. C. S.; TEIXEIRA, M. F. S.; DANTAS, D. J. O ensino de química por meio de atividades experimentais: a realidade do ensino nas escolas. In: NOBRE, S. L.; LIMA, J. M. (org.). Livro eletrônico do Segundo Encontro do Núcleo de Ensino de Presidente Prudente. São Paulo: Unesp, 2007.

CARVALHO. A. M. P. Uma metodologia de pesquisa para estudar. In: SANTOS, F. M. T.; GRECA, I. M. (org.). A pesquisa em ensino de ciências no Brasil e suas metodologias. ljuí: Editora Unijuí, 2006. p. 13-48.

CHALMERS, A. F. O que é ciência afinal? Tradução Raul Fiker. São Paulo: Brasiliense, 1993. 225p.

CONTRERAS, José. Autonomia de professores. Tradução Sandra Trabucco Valenzuela. São Paulo: Editora Cortez, 2002.

CORSO, A. M.; SOARES, S. T. O Ensino Médio no Brasil: dos desafios históricos às novas diretrizes curriculares nacionais. In: ANPED SUL, 10., Florianópolis, 2014. Anais Eletrônicos [...]. Florianópolis, out. 2014. Disponível em: http://xanpedsul.faed.udesc.br/arq_pdf/2085-0.pdf. Acesso em: 5 mar. 2019.

DEMO, P. Educação e qualidade. Campinas: Papirus, 1994.

FERNANDES, M. A. M. A abordagem da tabela periódica na formação inicial de professores de Química. Bauru, SP: Universidade Estadual Paulista, 2011.

FRIGOTTO, G. A produtividade da escola improdutiva: um (re) exame das relações entre educação e estrutura econômico-social e capitalista. 1. ed. São Paulo: Cortez, 1984.

GERHARDT, T. E.; SILVEIRA, D. T. (org.). Métodos de pesquisa. Porto Alegre: Ed. da UFRGS, 2009.

GIL, A. C. Como elaborar projetos de pesquisa. 5. ed. São Paulo: Atlas, 2010.

GRUNDY, S. Curriculum: Product or praxis. Londres: The Falmer Press, 1987.

HAGUETTE, T. M. F. Metodologias qualitativas na Sociologia. 5. ed. Petrópolis: Vozes, 1997.

HAMILTON, D. Sobre as origens dos termos classe e curriculum. Teoria e Educação, Porto Alegre, RS, n. 6, p. 33-52, 1992.

IBGE. Instituto Brasileiro de Geografia e Estatística. Censo Demográfico 2010: características da população e dos domicílios: resultados do universo. Rio de Janeiro: IBGE, 2010. Disponível em: http://www.ibge.gov. br/home/estatistica/populacao/censo2010/caracteristicas_da_populacao/resultados_do_universo.pdf. Acesso em: 9 mar. 2019.

JOHNSTONE, A. H. Macro and Microchemistry. The School Science Review, v. 64, n. 227, p. 377-379, 1982. KUENZER, A. Ensino Médio: construindo uma proposta para os que vivem do trabalho. São Paulo: Cortez, 2002.

LAKATOS, E. M.; MARCONI, M. A. Técnicas de pesquisa. 3. ed. São Paulo: Editora Atlas, 1996.

LIBÂNEO, J. C. Que destino os pedagogos darão à pedagogia? In: PIMENTA, S. G. (org.). Pedagogia, ciência da educação? São Paulo: Cortez, 1996.

LOPES, A. C. Conhecimento escolar: ciência e cotidiano. Rio de Janeiro: Uerj, 1999.

LOPES, A. C.; MACEDO, E. Teorias de currículo. São Paulo: Cortez, 2011.

LUCKEZI, C. C. Filosofia da educação. São Paulo: Cortez, 1994.

MALDANER, O. A.; ZANON, L. B. Situação de Estudo: uma organização curricular que extrapola a formação disciplinar em ciências. Espaços da Escola, v. 1, n. 41, p. 45-60, jul./set. 2001.

MALDANER, O. A.; ZANON, L. B.; AUTH, M.; NONENMACHER, S. E B.; BAZZAN, A. C.; PASCOAL, S. G. Situação de estudo como possibilidade concreta de ações coletivas interdisciplinares no Ensino Médio - ar atmosférico. In: ENCONTRO NACIONAL DE PESQUISA EM EDUCAÇÃO EM CIÊNCIAS, 3., 2001, Atibaia. Atas [...]. São Paulo: Abrapec, 2001.

MALDANER, O. A. Concepções epistemológicas no ensino de Ciências. In: MALDANER, O. A.; ZANON, L. B. Situação de Estudo: uma organização curricular que extrapola a formação disciplinar em ciências. Espaços da Escola, ljuí: Editora Unijuí, v. 1, n. 41, p. 45-60, jul./set. 2001.

MALDANER, O. A.; RITTER, J. Formação de professores no desenvolvimento de novas práticas curriculares: autonomia a ser construída. In: OSÓRIO, Mara Rejane Vieira; GOMES, Vanise dos Santos (org.). Formação, experiência docente e práticas escolares. 1. ed. Rio Grande: Editora da Furg, 2014. p. 101-130. V. 1.

MASETTO, M. T. Inovação curricular no Ensino Superior. Revista E-Curriculum, São Paulo, v. 7, n. 2, p. 1-20, ago. 2011.

MATUI, J. Construtivismo. São Paulo: Moderna, 1988.

MELO, M. S. A transição entre os níveis - macroscópico, submicroscópico e representacional - uma proposta metodológica. 2015, 134f. Dissertação (Mestrado) - Universidade de Brasília, Programa de Pós-Graduação em Ensino de Ciências, Mestrado Profissional em Ensino de Ciências, Brasília, 2015.

MORAES, R. Análise de conteúdo. Educação, XXII, n. 37, p. 7-32, mar. 1999. 
MORAES, R.; GALIAZZI, M. C. Análise Textual Discursiva. 2. ed. rev. ljuí: Editora Unijuí, 2011.

MORTIMER, E. F.; MACHADO, A. H.; ROMANELLI, L. I. A proposta curricular de química do Estado de Minas Gerais: fundamentos e pressupostos. Química Nova, v. 23, p. 273-283, 2000. ISSN 0100-4042. Disponível em: http://www.scielo.br/scielo.php?script=sci_arttext\&pid=S0100-40422000000200022\&nrm=iso. Acesso em: 25 mar. 2019.

NEWBOLD, B. T. Apresentar a química para o cidadão: um empreendimento social. In: CONFERÊNCIA INTERNACIONAL DE EDUCAÇÃO QUÍMICA, 1987, São Paulo. Anais [...]. São Paulo: Instituto de Química; Universidade de São Paulo, 1987. p. 155-173.

PINTOCO, V. M. Visão do professor sobre o número de alunos por turma: uma contribuição para a melhoria da qualidade da educação. 2017. 186f. Dissertação (Mestrado em Estudos Profissionais Especializados em Educação: Especialização em Administração das Organizações Educativas) - Instituto Politécnico do Porto, Porto, 2017.

PRUDÊNCIO, C. A. V. Perspectiva CTS em estágios curriculares em espaços de divulgação científica: contributos para a formação inicial de professores de Ciências e Biologia. 2013. Tese (Doutorado em Educação) - Universidade Federal de São Carlos, UFSCar, São Carlos, 2013.

RAMOS, M. N. O currículo para o Ensino Médio em suas diferentes modalidades: concepções, propostas e problemas. Educação \& Sociedade, Campinas, v. 32, n. 116, p. 771-788, jul./set. 2011.

RITTER, J. Processos de recontextualização das compreensões da educação para o século XXI em políticas públicas e práticas educacionais: sentidos e significados para a formação de competências. 2015. 292f. Tese (Doutorado) - Universidade Regional do Noroeste do Estado do Rio Grande do Sul, Campus ljuí e Santa Rosa, Educação nas Ciências, ljuí, 2015.

RITTER, J. Recontextualização de políticas públicas em práticas educacionais: novos sentidos para a formação de competências básicas. Curitiba: Editora Appris, 2017.

RITTER-PEREIRA, J. Os programas de Ensino de Química na educação básica na compreensão e prática de professores. 2011. 179f. Dissertação (Mestrado em Educação nas Ciências). - Universidade Regional do Noroeste do Estado do Rio Grande do Sul - Unijuí.

SACRISTÁN, J. G. El curriculum: una reflexión sobre la práctica. Madrid: Ed. Morata, 1995.

SACRISTÁN, J. G. O currículo: uma reflexão sobre a prática. Porto Alegre: ArtMed, 2000.

SANGIOGO, F. A.; HALMENSCHLAGE, K. R.; HUNSCHE, S.; MALDANER, O. A. Pressupostos epistemológicos que balizam a Situação de Estudo: algumas implicações ao processo de ensino e à formação docente. In: Ciência \& Educação, v. 19, n. 1, p. 35-54, 2013.

SANTOS, B. S. Introdução a uma ciência pós-moderna. Rio de Janeiro: Graal, 2000.

SANTOS, M. E. V. M. A cidadania na "voz" dos manuais escolares: O que temos? O que queremos? Lisboa: Livros Horizonte, 2001.

SANTOS, W. L. P. Significados da educação científica com enfoque CTS. In: SANTOS, W. L. P.; AULER, D. (org.). CTS e educação científica: desafios, tendências e resultados das pesquisas. 1. ed. Brasília: Editora da Universidade de Brasília, 2011. p. 21-42.

SANTOS, W. L. P.; MORTIMER, E. F. Concepções de professores sobre contextualização social do ensino de química e ciências. In: REUNIÃO ANUAL DA SOCIEDADE BRASILEIRA DE QUÍMICA, 22., 1999, Poços de Caldas. Anais [...]. Poços de Caldas: Sociedade Brasileira de Química, 1999.

SANTOS, W. L. P.; SCHNETZLER, R. P. Educação em Química: compromisso com a cidadania. 4. ed. Ijuí: Editora Unijuí, 2014.

SAVIANI, D. História das ideias pedagógicas no Brasil. São Paulo: Autores Associados, 2007.

SENGE, P. Conduzindo organizações voltadas para o aprendizado: o destemido, o poderoso e o invisível. In: HESSELBEIN, F.; GOLDSMITH, M.; BECKHARD, R. (org.). O líder do futuro. São Paulo: Futura, 1996. p. 121-125.

SILVA, M. A. História do currículo e currículo como construção histórico-cultural - trabalho completo. CONGRESSO LUSO-BRASILEIRO DE HISTÓRIA DA EDUCAÇÃO, 6., 2006, Uberlândia. Anais [...]. Uberlândia: Edufu, 2006. p. 4.820-4.828. V. 1.

SILVA, T. T. da. Documentos de identidade: uma introdução às teorias de currículo. 3. ed. Belo Horizonte: Editora Autêntica, 2009.

SILVA, A. V. M. da. A pedagogia tecnicista e a organização do sistema de ensino brasileiro. Revista HISTEDBR On-line, Campinas, n. 70, p. 197-209, dez. 2016.

SMOLKA, A. L. B. Sobre significação e sentido: uma contribuição à proposta de rede de significações. In: ROSSETTI-FERREIRA, M. C.; AMORIM, K. S.; SILVA, A. P. S.; CARVALHO, A. M. A. (org.). Rede de significações e o estudo do desenvolvimento humano. v.Porto Alegre: Artes Médicas. 2004. p. 35-49. V. 1. 


\section{\& Contexto}

O Currículo de Química na Educação Básica: concepções e práticas de professores

STRIEDER, R. B. Abordagens CTS na educação científica no Brasil: sentidos e perspectivas. Tese (Doutorado em Ensino de Física) - Faculdade de Educação, Instituto de Física, Instituto de Química e Instituto de Biociências, Universidade de São Paulo, 2012.

TANNER, D; TANNER, L. Curriculum development. New York: Macmillam, 1975.

VILELA, M. L.; VASCONCELLOS, D. V.; GOMES, M. M. Reflexões sobre abordagens didáticas de experimentos para o ensino de Ciências. Revista da SBEnBIO, v. 1, p. 12-15, 2005.

VYGOTSKY, L. Pensamento e Linguagem. 2. ed. São Paulo: Martins Fontes, 1998.

VYGOTSKY, L. Psicologia pedagógica. São Paulo: Martins Fontes, 2001.

WARTHA, E. J.; SILVA, E. L. da; BEJARANO, N. R. Cotidiano e contextualização no ensino de química. Revista Química Nova na Escola, v. 35, n. 2, p. 84-91, 2013. 